\title{
EFFECTS OF COVID-19-PANDEMIC LOCKDOWN OF CHURCHES IN NIGERIA ON PASTORAL MINISTRY: MATTERS ARISING ${ }^{1}$
}

\author{
Adebayo Ola Afolaranmi \\ $\mathrm{PhD}$ (Peace and Conflict Studies) \\ Student of Lead City University, \\ Ibadan Nigeria.
}

Article DOI: https://doi.org/10.36713/epra4637

\begin{abstract}
Many churches and other public places in Nigeria and other places throughout the world experienced lockdown as result of the ravaging COVID-19 pandemic. These affected church activities and pastoral ministry of many church pastors greatly. In response to this lockdown and its negative effects, many pastors in Nigeria start to explore other ways to perform their pastoral ministry to their church members. This study explores how pastors are performing their pastoral ministry to their church members during the COVID-19 pandemic lockdown. Some open-ended questions were sent randomly to some pastors through WhatsApp Messenger. The pastors responded either by WhatsApp or email. There were further correspondences with some of the respondents through WhatsApp and phone calls. The findings of the study revealed that while some of the respondents were still using some of the old traditional means of pastoral ministry during the lockdown, many pastors have started adapting to the current situation by exploring other possible means to perform their pastoral ministry to their church members. One prominent means is Internet ministry. Many of the respondents bear their minds on how pastors can respond productively to the situation. Some recommendations and suggestions for further study are made at the end of the paper.
\end{abstract}

KEYWORDS: Nigerian church, pastoral ministry, COVID-19 pandemic, Internet ministry, lockdown

\section{AUTHOR'S DETAILS}

Adebayo Ola Afolaranmi (an ordained pastor of the Nigerian Baptist Convention) has a Master of Theology in Religious Education from the Nigerian Baptist Theological Seminary, Ogbomoso, Nigeria and a Master of Philosophy in Conflict Resolution and Reconciliation from Trinity College Dublin, Republic of Ireland. He is presently a PhD (Peace and Conflict Studies) student of Lead City University, Ibadan Nigeria. He used to coordinate the Internet ministry at the headquarters of the Nigerian Baptist Convention, Baptist Building, Oke Bola, Ibadan. He is the Chief Responsibility Officer of The Word through the Internet - a ministry through the Internet and other technological tools. He can be reached by by phone and other various social media on +2348055159591 . His ORCID iD: https://orcid.org/0000-00018057-137X.

\section{INTRODUCTION}

Coronavirus disease (also called COVID-19, 2019-nCov, 2019 Novel Coronavirus) - an infectious disease caused by a new virus that had not been previously identified in humans and causes respiratory illness (like the flu) with symptoms such as a cough, fever and in more severe cases, pneumonia $^{2}$ - started around December 2019 in Wuhan, China. ${ }^{3}$ It ravaged the world unabated in the year 2020 as the pandemic spread like wild fire to every part of the world within months of its outbreak. As parts of efforts to curtail its spread, churches and other public places were locked down in the late March 2020. When this took place, little did the church leaders and other people know that it would take months for churches in particular and other public places in general to be opened again for large gathering. Church leaders with the cooperation of 
their church members started looking for alternative ways of worship and doing other church activities.

\section{STATEMENT OF THE PROBLEM}

Against the backdrop that the lockdown of churches and other public places have prevented pastors from performing their pastoral ministry in the traditional ways through physical contacts, churches had to find other means of holding their church activities, and pastors had to explore alternative means of performing their pastoral ministry. Therefore, this paper is an attempt to find out the effects of the COVID-19 lockdown and how the church can move forward, especially how pastors can be more effective in their pastoral ministry, after the churches are re-opened for congregational gatherings.

\section{CONCEPTUAL FRAMEWORK PASTORAL MINISTRY}

This conceptual framework is based on a review of Ağılkaya-Şahin (2016)'s “Theoretical Foundations of Pastoral Care in Christian Tradition". ${ }^{4}$ In Ağılkaya-Şahin (2016)'s article, the concept of pastoral ministry is "illustrated in terms of definition, characteristics, subjects, objects, aims, tasks and theology." 5 The aim of pastoral ministry, otherwise referred to as pastoral psychology, is to help persons with their religious and non-religious challenges through a religious framework of interdisciplinary work of theology and human/social sciences. ${ }^{6}$ This aim varies "according to time and approach". ${ }^{7}$ The word "pastoral" is derived from the concept of shepherding as adopted by the Early Church. This concept of pastoral care is based on the qualities underscored in the Bible, "such as consolation, resolution, counseling, and healing." spite of the fact that it is difficult to give a precise definition of pastoral ministry, however, it can be described as the art of helping "in improving people's religious and ethical development" or "psychotherapy in the context of the Church". 9 Characteristically, pastoral ministry "provides mutual help, enforcement, and possibilities" 10 for people that need spiritual assistance or want to grow in their spiritual lives. Theologically, pastoral ministry is "embedded in Christian scripture". 11 The Christian scripture presents God as the first pastoral minister who did, and is doing, pastoral ministry in creating and sustaining the heavens and the earth, sending Jesus Christ to the world to die for the sin of the world, selecting the first apostles to continue the earthly pastoral ministry of Jesus Christ, and enabling the first apostles to pass on the baton on pastoral ministry to other believers in Jesus Christ (especially the clerics). Although pastoral ministry is not specifically found in the Christian scripture, Ağılkaya-Şahin (2016) concluded his treatise by highlighting some concepts of pastoral ministry found in the Christian scripture and their scriptural references. ${ }^{12}$

\section{COVID-19-PANDEMIC LOCKDOWN}

As part of the efforts to curtail the spread of COVID-19 pandemic, governments throughout the world started to restrict gathering of large number of people in public places and movements from one place to the other, especially interstate and crossborder movements, and advocate stay safe or stay at home. It also involves what is termed social (or preferably physical) distancing - "a way to keep people from interacting closely or frequently enough to spread an infectious disease" where "schools and other gathering places such as movie theaters may close, and sports events and religious services may be cancelled."13 This restriction is popularly known as lockdown. With the advent of a COVID-19 case in Nigeria on February 27, 2020, the Nigerian governments at the federal and state levels started imposing series of lockdown measures. 14 Undoubtedly, this lockdown affected churches and the ways pastors are performing their pastoral ministry among the church members. ${ }^{15}$

\section{TARGETED POPULATION, INSTRUMENT AND PROCEDURE FOR DATA COLLECTION}

The targeted population of this study was randomly selected Nigerian pastors that are young, intermediate or older in pastoral ministry. The instrument used to collect data for the study is a form of open-ended questions sent to respondents through WhatsApp Messenger, and the respondents sent in their responses through either WhatsApp Messenger or email. As occasions demanded it, there were further correspondences with some of the respondents through WhatsApp Messenger or phone calls. This researcher adapted and employed this means for his data collection because of the current situation in the world that discouraged people from moving from one place to the other and the advocacy for social/physical distancing and staying safe. The time frame of this research is the months of March to May 2020.

\section{DATA PRESENTATION AND DISCUSSIONS OF RESULTS NUMBER OF RESPONDENTS}

Out of one hundred and fifty (150) pastors that were contacted through WhatsApp Messenger, one hundred and seventeen (117) responded. This represented seventy-eight per cent (78\%) of the total number of people contacted. With this percentage, this researcher is of the opinion that this method of data collection is considerable better, more effective and more result-oriented to other methods of data collection in social sciences research. 


\section{YEARS OF EXPERIENCE IN PASTORAL MINISTRY}

Figure 1: Years of Experience in Pastoral Ministry

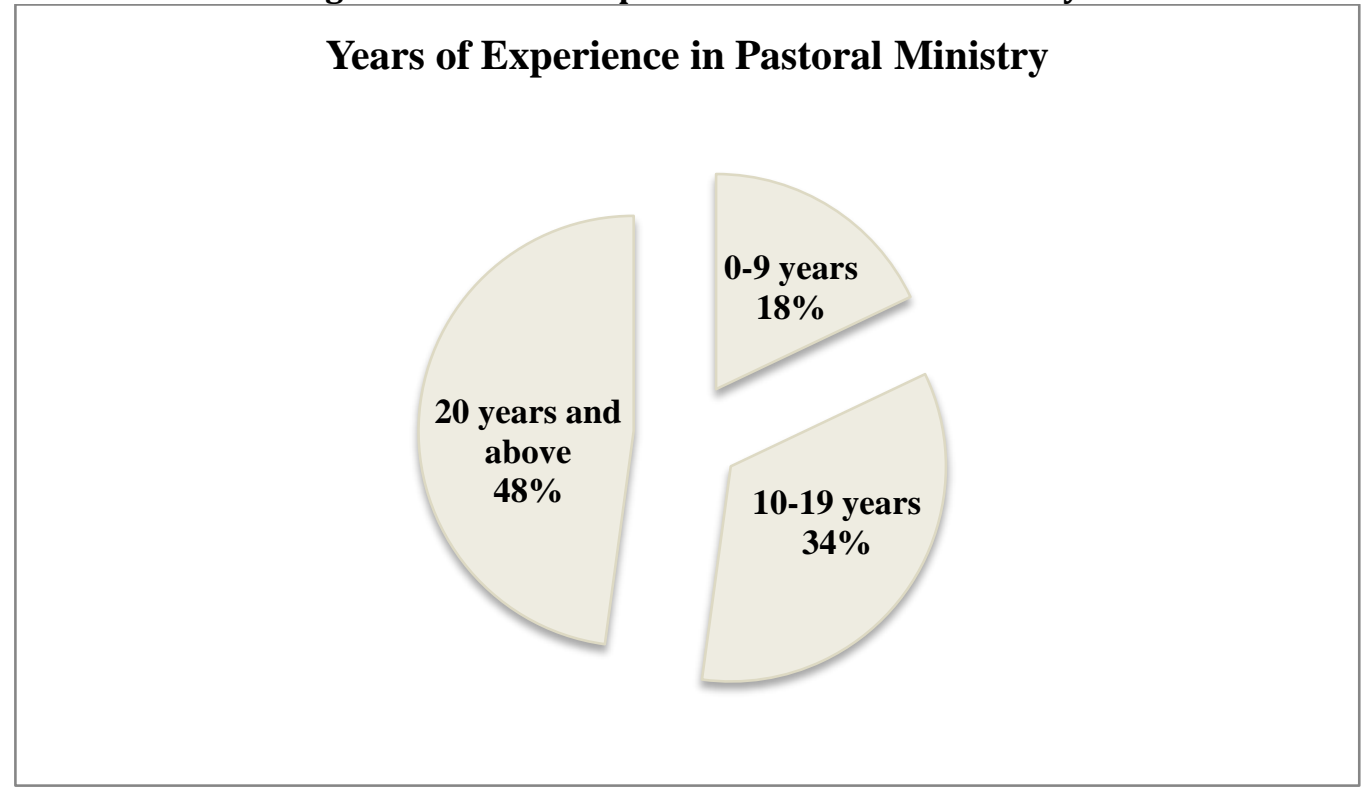

From the number of pastors that responded as shown in Figure 1, twenty-one (21) respondents that represent eighteen per cent $(18 \%)$ have had pastoral ministry experiences for less than 9 years, forty (40) respondents that represent thirty-four per cent $(34 \%)$ have had pastoral ministry experiences between 10 and 19 years, while fifty-six (56) respondents that represent forty-eight per cent (48\%) have had pastoral ministry experiences for at least 20 years. This result shows that most of the respondents are experienced pastors in their pastoral ministry. It is has to be noted here that few of these respondents are missionaries while some are teachers in pastors' training schools. This exception is reflected in the responses of these particular pastors. 


\section{MAJOR TRADITIONAL WAYS OF PASTORAL MINISTRY BEFORE COVID-19 PANDEMIC PERIOD}

Figure 2: Major Traditional Ways of Pastoral Ministry before COVID-19 Pandemic Period

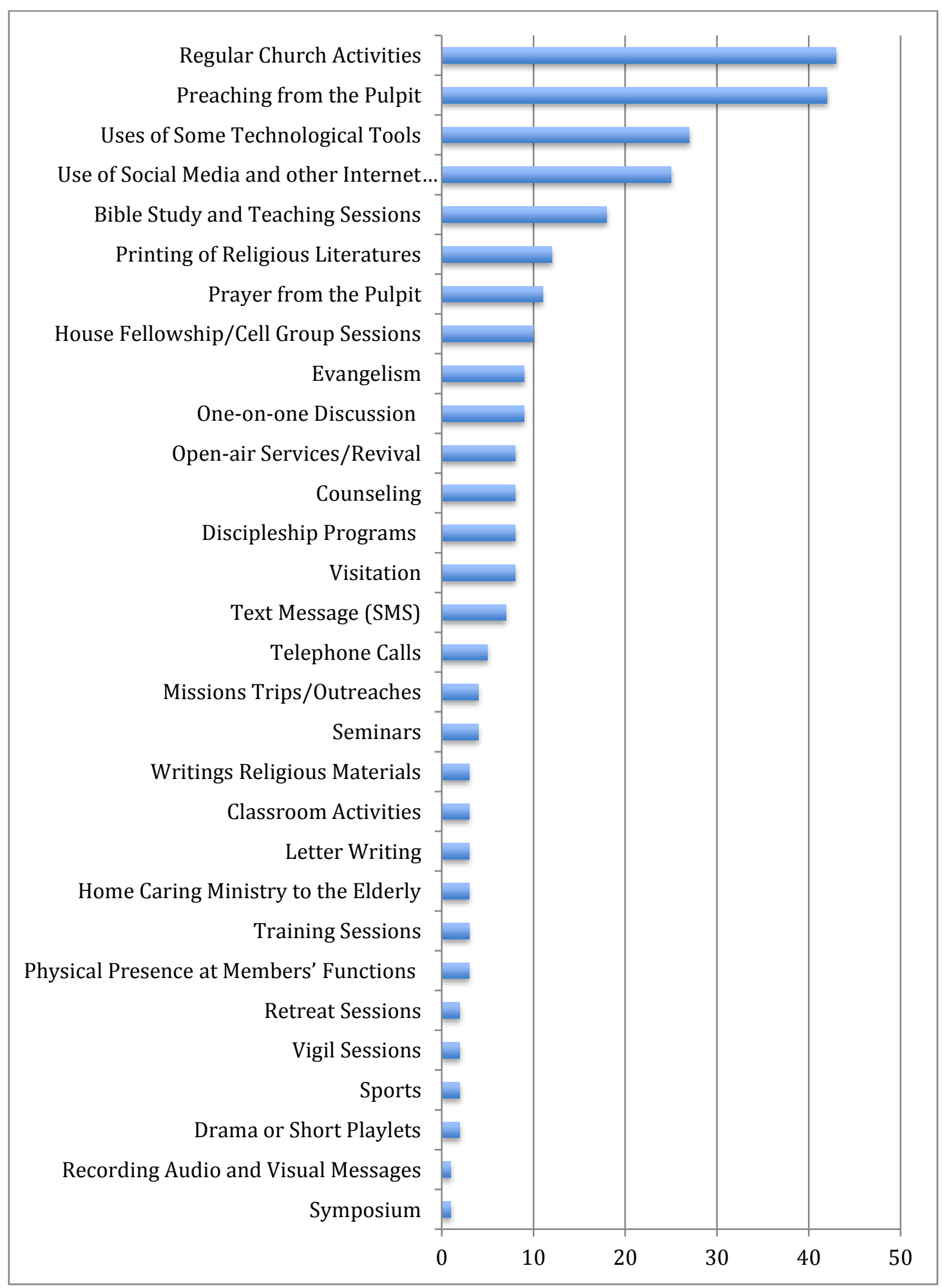


It is evident that as their main responsibility, pastors have been performing their pastoral ministry in various ways before the outbreak of COVID-19 pandemic that caused some restrictions to curtail the spread of the pandemic. The respondents identified some of these ways as represented by Figure 2. These responses do not mean a respondent chose only one response. The respondents had the opportunity of identifying as many ways as possible. The responses indicate that each of them has been using many ways to perform his pastoral ministry before the outbreak of COVID-19 pandemic.

A quick glance at the Figure 2 shows that attending (and in most cases presiding over) regular church activities (43 respondents representing 36\%) is most noticeable means of pastoral ministry among the respondents. These activities include the conventional gatherings mostly on Sundays and some other days during the week. Preaching from the pulpit is the second most recognizable way many of the respondents (42 respondents representing 35\%) indicated as the traditional way of engaging in pastoral ministry before the COVID-19 pandemic period. Two other more recognizable ways are uses of some technological tools (27 respondents representing $23 \%$ ) and uses of social media and other Internet platforms (25 respondents representing $21 \%$ ). This indicates that some of the respondents are technologically inclined in their pastoral ministry. Other ways that have respondents between 10 and 20 (representing $8 \%$ and 17\%) are prayer from the pulpit, Bible study and teaching sessions, house fellowship/cell group sessions, and printing of religious literatures.

\section{WAYS OF PASTORAL MINISTRY DURING COVID-19 PANDEMIC}

Table 1: Ways of Pastoral Ministry During COVID-19 Pandemic

\begin{tabular}{|c|c|}
\hline Ways of Pastoral Ministry During COVID-19 Pandemic & $\begin{array}{l}\text { Numbers of } \\
\text { Respondents }\end{array}$ \\
\hline WhatsApp Group & 74 \\
\hline Facebook & 55 \\
\hline Social Media Platforms & 48 \\
\hline House Fellowship/House Cell Church & 43 \\
\hline Telephone (for counselling and prayers) & 41 \\
\hline Zoom & 37 \\
\hline YouTube Media Channels of the Church & 32 \\
\hline Text Message (SMS) & 29 \\
\hline Facebook Live Streaming & 19 \\
\hline Telegram Messenger & 17 \\
\hline Sunday Service Online & 16 \\
\hline Email & 15 \\
\hline Teleconference & 15 \\
\hline Recorded Messages and Songs & 14 \\
\hline Weekly Radio Broadcast & 14 \\
\hline Multiple Number of Services per Sunday & 13 \\
\hline Conference Call & 13 \\
\hline Visitation & 13 \\
\hline Online Prayers Sessions & 13 \\
\hline Family Fellowship & 12 \\
\hline Typing of Messages & 12 \\
\hline Website Posting & 12 \\
\hline Personal Counselling (for few emergencies) & 12 \\
\hline Twitter & 12 \\
\hline Instagram & 12 \\
\hline Video Recording & 12 \\
\hline Physical Ministration & 10 \\
\hline Internet Radio & 8 \\
\hline Transferable Videos, Audio and Text & 7 \\
\hline Webinar & 6 \\
\hline Imo Messenger & 6 \\
\hline Distribution of Relief Packages & 5 \\
\hline Print Media & 5 \\
\hline Use of Google Forms & 5 \\
\hline Online Class Sessions & 5 \\
\hline
\end{tabular}




\begin{tabular}{ll}
\hline Sharing of God's Word Early in the Morning & 5 \\
Television & 5 \\
Paying Tithe through Online Banking Transfer & 5 \\
Google Classroom & 4 \\
\hline
\end{tabular}

A question was posed to the respondents on how they are doing pastoral ministry during the COVID19 pandemic period. This is a subjective question that allowed the respondents to give as many answers as possible. As shown in Table 1, there are still some traditional ways of pastoral ministry like house fellowship/cell church (43 respondents representing $36 \%$ ), telephone calls for counselling and prayers (41 respondents representing 35\%), weekly radio broadcast (14 respondents representing 12\%), physical ministrations to limited number of people (10 respondents representing 8\%), multiple number of services per Sunday (13 respondents representing $11 \%$ ), visitation (13 respondents representing $11 \%$ ), personal counselling for few emergencies (12 respondents representing $10 \%$ ), distribution of relief packages (5 respondents representing 4\%), and sharing of God's Word early in the morning (5 respondents representing 4\%). However, most of the ways indicated as shown in Table 1 as the ways of pastoral ministry during the pandemic are Internetinclined (369 responses representing 315\%). This clearly indicates that apart from the earlier identified traditional means of pastoral ministry, various aspects of the Internet ministry take a very major role in the pastoral ministry of respondents to their church members during the pandemic.

\section{MORE FINDINGS}

Many of the respondents used the opportunity of the research to bear their minds on the effects of the pandemic lockdown on church activities and especially performing pastoral ministry in a time like this. Some of these opinions are given here. A respondent was of the opinion that "...the development and the exposure brought about by the experience of COVID-19 has obviously created a shift from what pastors have been doing before the outbreak of the pandemic and what [pastors] have to do after we overcome the pandemic." This respondent went further to say that pastors that are not ready to adapt with this shift may be overtaken by time and become irrelevant in pastoral ministry in the post-COVID-19-pandemic world. Another respondent agreed with this position and encouraged pastors to understand the current trend in the society and take advantage of every resource at present to serve as platform for pastoral ministry. Pastors can do this by improving and developing themselves to be relevant in this current trend. One selfdevelopment that is paramount, according to many of the respondents, is the knowledge of the new trends in information and communication technologies (ICT) as the world is now more technologically driven. ${ }^{16}$ Another finding is that the pandemic has revealed that pastors should be more concerned about the needs and situations of their church members apart from the traditional weekly messages during Sunday worships. Church members are going through a lot of challenges occasioned by the pandemic. ${ }^{17}$ This is the time that pastors should be more passionate to show that they really care for the church members. This care can be in form of visitation (if possible), phone calls, sending of encouraging text messages, leading the church to give monetary or material tokens to needy church members, and other ways that will make the church members to feel the positive impacts of the pastors and the churches in their lives and situations. Pastors are enjoined to be more dynamic in the way they are conducting their church activities and other aspects of pastoral ministry. They are to make necessary adjustment in their service plans and messages (through sermons and Bible teachings). The age of parochialism is over. New innovations are needed in pastoral ministry to combat the challenges that the COVID-19 pandemic has posed to the world.

\section{RECOMMENDATIONS AND CONCLUSION}

The initial aim of this study was to explore the possibility of Internet ministry as an alternative means of pastoral ministry during the COVID-19 pandemic in Nigeria. The study indeed revealed that Internet ministry - the use of the Internet and other technological tools in Christian ministries in general and pastoral ministry in particular ${ }^{18}$ - has become an alternative avenue for pastoral ministry. ${ }^{19}$ However, the study also revealed that there are others means of pastoral ministry that are needed to be more encouraged while some are needed to be less encouraged. As enumerated above, pastors are advised to tackle the challenges of the COVID-19 pandemic dynamically. Therefore, these additional recommendations ${ }^{20}$ are made:

1. Every pastor should study the uniqueness of his congregation and locality and fashion out how to respond to the challenges that the COVID-19 pandemic has posed in the context of the peculiarity of his congregation and locality.

2. Pastors should embrace the use of the Internet and other technological tools in their pastoral ministry. While the traditional physical means of pastoral ministry should be continued as much as possible, pastors should be thinking of how to make Internet ministry not only an alternative ministry, but 
also as supplementary to the traditional ways of pastoral ministry.

3. Churches should invest more in their multimedia ministry ${ }^{21}$ by training pastors on how to use several tools to enhance the multimedia ministry, and by training some church members to assist the pastors and the church in the use of technological tools for ministry.

4. Pastors should consciously teach church members to be able to stand without depending on the pastors or church activities during trying times.

5. Pastors should train some committed church members some rudiments of pastoral ministry so that such trained people will be able to assist the pastors in the pastoral ministry.

6. Multi-staff ministry (that will involve a group of Christian persons - not necessarily trained pastors - who are committed to serve God by serving other members of the church to enable the church achieve its missions and responsibilities ${ }^{22}$ ) should be encouraged even in the remote or smallest churches.

7. Less emphasis should be placed on large congregational gathering while more emphasis should be place on small groups in forms of cell churches, house fellowships, home fellowships, and the likes.

8. Less emphasis should also be placed on constructing large auditoria while more emphasis should placed on activities that will build the church members up in their spiritual lives.

9. More efforts should be given to visitation and caring of church members through phone calls and sending of text messages.

\section{SUGGESTIONS FOR FURTHER \\ STUDY}

Based on the outcome of this study, the following are recommended for further study:

1. Coping with challenges of post-COVID-19 pandemic.

2. Revisiting the cell church/house fellowship system.

3. Effectiveness of multi-staff ministry in the contemporary world.

Funding: This research received no external funding.

Conflicts of Interest: The author declares no conflict of interest. 


\section{ENDNOTES}

\footnotetext{
${ }^{1}$ This paper is a follow-up paper from a study carried out by this researcher on a theme on Internet ministry as an alternative means of pastoral ministry in churches in Nigeria during the COVID-19 pandemic situation. The premier paper is presently under consideration for publication in another journal. Therefore, some of the information in this paper is directed extracted from the other paper by the same researcher.

${ }^{2}$ Yan-Rong Guo, et al (2020). "The origin, transmission and clinical therapies on coronavirus disease 2019 (COVID19) outbreak - an update on the status". Military Medical Research (2020) 7:11. Retrieved May 30, 2020 from https://doi.org/10.1186/s40779-020-00240-0, 2.

${ }^{3}$ Lo'ai Alanagreh, Foad Alzoughool and Manar Atoum (2020). "The Human Coronavirus Disease COVID-19: Its Origin, Characteristics, and Insights into Potential Drugs and Its Mechanisms". Pathogens 2020, 9, 331. Retrieved May 30, 2020 from https://doi:10.3390/pathogens9050331, 1.

${ }_{4}^{4}$ Zuhâl Ağllkaya-Şahin (2016). "Theoretical Foundations of Pastoral Care in Christian Tradition". Spiritual Psychology and Counseling, 1, 65-74. Retrieved May 27, 2020 from http://dx.doi.org/10.12738/spc.2016.1.0002.

${ }_{6}^{5}$ Ağllkaya-Şahin, 65.

${ }^{6}$ Ăgllkaya-Şahin, 66.

${ }^{7}$ Ağllkaya-Şahin, 70.

${ }^{8}$ Ağllkaya-Şahin, 67.

${ }^{9}$ Ağllkaya-Şahin, 68-69.

${ }^{10}$ A $\breve{g l l k a y a-S ̧ a h i n, ~} 69$.

${ }_{11}$ A ğllkaya-Şahin, 70.

12 A ̈̆llkaya-Şahin, 71-72.

13 "Tips For Social Distancing, Quarantine, And Isolation During An Infectious Disease Outbreak". Retrieved March 28, 2020 from https://www.samhsa.gov/sites/default/files/tips-social-distancing-quarantine-isolation-031620.pdf, p. 1.

${ }_{14}^{14}$ Peterson Ozili (2020). "Covid-19 pandemic and economic crisis: The Nigerian experience and structural causes". International Journal of Sociology and Social Policy, 2020. Retrieved June 7, 2020 from http://dx.doi.org/10.2139/ssrn.3567419, 2.

${ }^{15}$ Oyelola A. Adegboye, Adeshina I. Adekunle, and Ezra Gayawan (2020). "Early Transmission Dynamics of Novel Coronavirus (COVID-19) in Nigeria”. International Journal of Environmental Research and Public Health. 2020, 17, 3054. Retrieved May 30, 2020 from https://dx.doi.org/10.3390/ijerph17093054, 7.

${ }^{16}$ Wayne F. Cascio and Ramiro Montealegre (2016). "How Technology Is Changing Work and Organizations". Annual Review of Organizational Psychology and Organizational Behavior. Volume 3, 2016. Retrieved June 10, 2020 from https://www.annualreviews.org/doi/abs/10.1146/annurev-orgpsych-041015-062352, 350

${ }^{17}$ See Chukwuka Onyekwena and Mma Amara Ekeruche (2020). "Understanding the impact of the COVID-19 outbreak on the Nigerian economy". Retrieved June 10, 2020 from https://www.brookings.edu/blog/africa-infocus/2020/04/08/understanding-the-impact-of-the-covid-19-outbreak-on-the-nigerian-economy/.

${ }^{18}$ See Adebayo Ola Afolaranmi (2009). Ministering through the Internet: An Essential Guide (Ibadan: Charisa Books \&Publishing), 39-44.

${ }^{19}$ Specific findings and recommendations on Internet ministry as an alternative means in pastoral ministry have been presented in the earlier paper by this researcher under consideration for publication in another journal.

${ }^{20}$ Some of these recommendations are extracted from the additional comments given by the respondents.

${ }^{21}$ For more on multimedia ministry, see Adebayo Afolaranmi (2019). "Effective Use of Technological Tools in Building the Church's Educational Ministries". Retrieved June 10, 2020 from https://www.academia.edu/40251074/, 1.

${ }^{22}$ See Jerry W. Brown (1973). Church Staff Team That Wins (Nashiville: Convention Press), 23.
} 